NBER WORKING PAPER SERIES

REAL EXCHANGE RATES AND PRODUCTIVITY GROWTH IN THE UNITED STATES AND JAPAN

Richard C. Marston

Working Paper No. 1922

NATIONAL BUREAU OF ECONOMIC RESEARCH 1050 Massachusetts Avenue

Cambridge, MA 02138

May 1986

The research reported here is part of the NBER's research program in International studies. Any opinions expressed are those of the author and not those of the National Bureau of Economic Research. 


\title{
Real Exchange Rates and Productivity Growth in the United States and Japan
}

\begin{abstract}
Real exchange rates between the yen and dollar based on general price indexes overestimate the competitiveness of the United States relative to Japan. High productivity growth in the traded sector of the Japanese economy results in a continuous fall in the prices of traded goods relative to nontraded goods in Japan. In order to keep U.S. traded goods competitive, the real exchange rate based on general price series like the GDP deflator or the CPI index must continually fall resulting in a real appreciation of the yen. This paper provides estimates of how far real exchange rates based on general price series would have had to fall over the $1973-83$ period in order to keep U.S. traded goods competitive. The real exchange rate based on GDP deflators, for example, would have had to fall by $38 \%$ relative to the real exchange rate based on unit labor costs in the traded sector. The GDP series remained roughly constant over the period, thus giving the misleading impression that U.S. goods were still competitive despite a sharp rise in the relative price of U.S. traded goods. The paper also provides estimates of the relative wage changes which would have to occur to restore the competitiveness of U.S. traded goods.
\end{abstract}

Richard C. Marston Wharton School University of Pennsylvania 2300 Steinberg-Dietrich Hall Philadelphia, PA 19104 
REAL EXCHANGE RATES AND PRODUCTIVITY GROWTH

IN THE UNITED STATES AND JAPAN*

The recent misalignment of the dollar relative to the yen has obscured the effects of a longer-term influence on the relative competitiveness of the two economies, productivity growth in Japan. For the past few decades, productivity growth has been much more rapid in Japan than in the United States. Such a gap in productivity performance would not ordinarily affect real exchange rates except that productivity growth is concentrated in the traded sectors of both economies. Thus through time, the prices of traded relative to nontraded goods must adjust to reflect productivity gains, but this adjustment is much more extensive in Japan. As a result, the U.S. general price level must continually fall relative to the Japanese price level, when both are measured in a common currency, just to keep U.S. traded goods competitive.

In the extensive literature on the purchasing power parity (PPP) theory of exchange rates, a number of studies have cited productivity differentials between the nontraded and traded sectors of economies as a prime cause of deviations between any exchange rate and its PPP value. Several of these studies, including Balassa (1964, 1973), De Vries (1968), Clague and Tanzi (1972), and Officer (1976b), have reported empirical tests of this phenomenon, but have differed widely in their conclusions about whether productivity differentials explain deviations from PPP. ${ }^{1}$ Hsieh's (1982) recent study using time series rather than cross section data, however, has provided strong evidence supporting the role of productivity differentials. ${ }^{2}$

The real exchange rates used in the present study, defined as the nominal exchange rate (yen/dollar) adjusted for the relative prices of U.S. and Japanese goods, measure departures from PPP defined in terms of several 
alternative price indexes. This study, however, is less concerned with whether PPP holds or does not hold than with assessing the quantitative effects of productivity differentials between the United States and Japan on the alternative real exchange rates between the yen and dollar. ${ }^{3}$ The rapid productivity growth in the traded sector of the Japanese economy requires a continuing adjustment of real exchange rates between the yen and dollar measured in terms of general price indexes to keep U.S. goods competitive with Japanese goods. Similarly, the sharp changes in the prices of raw materials since 1973, which have affected the U.S. and Japanese economies in different ways, also require adjustments in real exchange rates.

Movements in real exchange rates over time are influenced by numerous short term demand factors in addition to the supply factors emphasized in this paper. The differential movement between two real exchange rates, however, should be primarily influenced by supply factors such as productivity differentials rather than short term demand factors. For that reason, the expressions we develop below measure the real exchange rate based on one price series relative to that based on an alternative price series. In the case of the United States and Japan, supply factors lead to a widening gap between real exchange rates based on the consumer price index or wholesale price index and those based on traded goods alone. Estimating the magnitude of this gap is important since the relative competitiveness of these two economies is of ten determined by examining movements in real exchange rates based on the broader price indexes. The analysis will show that any appreciation of the yen large enough to restore real exchange rates based on such indexes to their levels prior to the recent misalignment would fall far short of restoring U.S. traded goods to their previous levels of competitiveness. For the same reasons, both nominal and real wages in the United States would have to 
decline relative to those in Japan just to restore previous levels of competitiveness.

The paper is also concerned with productivity performance within the manufacturing sector alone and its effects on relative prices within that sector. The analysis shows that the differentials in productivity growth between the United States and Japan at the industry level are highly correlated with the rates at which relative prices change within these same industries. Because these productivity changes have been so different across industries within manufacturing, with Japanese productivity growth exceeding U.S. growth by widely differing margins depending on the industry, the relative competitiveness of individual industries has changed radically. This would continue to be true even if the real exchange rate for manufactured goods as a whole were restored to historical levels.

The first section of the paper develops equations for real exchange rates defined in terms of value added deflators, relative unit labor costs, and general price indexes. These equations relate real exchange rates to productivity differentials in the nontraded and traded sectors of each economy and, in the case of general price indexes, to the real prices of raw materials. The empirical section of the paper begins with an analysis of how much real exchange rates based on the GDP deflator and consumer price index must diverge from those based on the prices of traded goods in order for the two economies to remain competitive. The next part examines the implications of these movements in real exchange rates for relative wages in the two countries. In the final part of the paper, disaggregated data for manufacturing are used to examine the productivity and relative price behavior of individual industries. 
SECTORAL PRODUCTION PATTERNS AND REAL EXCHANGE RATES

Real exchange rates based on alternative price indexes can diverge sharply when there are changes in productivity and relative prices within national economies. This section develops expressions for several real exchange rates to show how they are affected by such supply factors. The real exchange rates range from one based on the value added deflator for traded goods to a broader series based on the consumer price index.

Output and prices

We begin by outlining a simple production structure which distinguishes between gross output and value added and which divides output into traded and nontraded sectors. The production and gross output in one sector is assumed to be separable into value added and two types of inputs, raw materials and the output of the other sector. For simplicity, all production functions are assumed to be of the Cobb-Douglas form, although the expressions developed below could be interpreted as linearizations of a CES production function. 4 Equations 1a (or 1b) express value added in the traded (nontraded) sector, $V_{\mathrm{T}}$, as a function of employment in that sector, $\mathrm{L}_{\mathrm{T}}$, and capital, $\mathrm{K}_{\mathrm{T}}$, as well as a productivity factor represented by a time trend.

$$
\begin{gathered}
\mathrm{V}_{\mathrm{T}}=\left(1-\mathrm{c}_{\mathrm{T}}\right) \mathrm{L}_{\mathrm{T}}+\mathrm{c}_{\mathrm{T}} \mathrm{K}_{\mathrm{T}}+\mathrm{h}_{\mathrm{T}} \mathrm{t}, \\
\mathrm{V}_{\mathrm{N}}=\left(1-\mathrm{c}_{\mathrm{N}}\right) \mathrm{L}_{\mathrm{N}}+\mathrm{c}_{\mathrm{N}} \mathrm{K}_{\mathrm{N}}+\mathrm{h}_{\mathrm{N}} \mathrm{t}, \\
\mathrm{Z}_{\mathrm{T}}=\mathrm{c}_{\mathrm{T} 1} \mathrm{~V}_{\mathrm{T}}+\mathrm{c}_{\mathrm{T} 2} \mathrm{Z}_{\mathrm{NT}}+\mathrm{c}_{\mathrm{T} 3} \mathrm{I}_{\mathrm{T}}, \quad \mathrm{c}_{\mathrm{T} 1}+\mathrm{c}_{\mathrm{T} 2}+\mathrm{c}_{\mathrm{T} 3}=1 \\
\mathrm{Z}_{\mathrm{N}}=\mathrm{c}_{\mathrm{N} 1} \mathrm{~V}_{\mathrm{N}}+\mathrm{c}_{\mathrm{N} 2} \mathrm{Z}_{\mathrm{TN}}+\mathrm{c}_{\mathrm{N} 3} \mathrm{I}_{\mathrm{N}}, \quad \mathrm{c}_{\mathrm{N} 1}+\mathrm{c}_{\mathrm{N} 2}+\mathrm{c}_{\mathrm{N} 3}=1
\end{gathered}
$$

All variables are expressed in logs with their differences interpreted as percentage changes in the underlying variables. Equation 1c expresses gross 
output in the traded sector, $\mathrm{z}_{\mathrm{T}}$, as a function of value added in that sector as well as output in the nontraded sector used in the traded sector, $\mathrm{Z}_{\mathrm{NT}}$, and the input of raw materials, $\mathrm{I}_{\mathrm{T}}$. Equation 1d expresses gross output in the nontraded sector, $\mathrm{Z}_{\mathrm{N}}$, in analogous fashion. This specification, which allows the output of one sector to serve as an input in the other sector, is especially necessary in the case of traded goods since (nontraded) services often constitute a significant proportion of the final value of traded goods.

Parallel to these production functions are a set of price equations which implicitly define the value added deflators for each sector. The price of gross output in the traded (nontraded) sector, $\mathrm{P}_{\mathrm{T}}$, is a function of the value addied deflator for that sector, the gross output price in the other sector, and the price of raw materials.

$$
\begin{aligned}
& \mathrm{P}_{\mathrm{T}}=\mathrm{c}_{\mathrm{T} 1} \mathrm{P}_{\mathrm{VT}}+\mathrm{c}_{\mathrm{T} 2} \mathrm{P}_{\mathrm{N}}+\mathrm{c}_{\mathrm{T} 3} \mathrm{P}_{\mathrm{I}}, \\
& \mathrm{P}_{\mathrm{N}}=\mathrm{c}_{\mathrm{N} 1} \mathrm{P}_{\mathrm{VN}}+\mathrm{c}_{\mathrm{N} 2} \mathrm{P}_{\mathrm{T}}+\mathrm{c}_{\mathrm{N} 3} \mathrm{P}_{\mathrm{I}} .
\end{aligned}
$$

Because the price equations are dual to the production functions, the same production parameters appear in the production and price equations. These equations suggest that gross output prices can diverge from their value added counterparts either because of price developments in the other sector or changes in raw materials prices.

We are also interested in the relationship between the value added deflator, on the one hand, and wages and productivity, on the other hand. The marginal productivity relationships derived from $1 \mathrm{a}$ and $i b$ give such a relationship, provided that we assume that the markups of prices over marginal costs are constant: 


$$
\begin{aligned}
& P_{V T}=W_{T}-H_{T}, \\
& P_{V N}=W_{N}-H_{N} .
\end{aligned}
$$

Equation ( $3 a$ ) relates $\mathrm{P}_{\mathrm{VT}}$ to wages in the traded sector, $\mathrm{W}_{\mathrm{T}}$, and to productivity, $\mathrm{H}_{\mathrm{T}}$, which is defined as

$$
\mathrm{H}_{\mathrm{T}}=\mathrm{V}_{\mathrm{T}}-\mathrm{L}_{\mathrm{T}}=\mathrm{c}_{\mathrm{T}}\left(\mathrm{K}_{\mathrm{T}}-\mathrm{L}_{\mathrm{T}}\right)+\mathrm{h}_{\mathrm{T}} \mathrm{t}
$$

This productivity variable, $\mathrm{H}_{\mathrm{T}}$, reflects not only the productivity factor in the production function, $h_{\mathrm{T}} \mathrm{t}$, but also the capital deepening factor, $\mathrm{K}_{\mathrm{T}}-\mathrm{L}_{\mathrm{T}}$. It is this measure of productivity which affects value added prices, and hence the relative competitiveness of economies. Similarly, equation $3 b$ relates value added in the nontraded sector to wages and productivity in that sector.

The value added deflators in the two sectors together make up the value added deflator for the economy as a whole, $\mathrm{P}_{V}$, which is defined as follows:

$$
P_{V}=g P_{V N}+(1-g) P_{V T}
$$

We choose to define the value added deflator as a weighted average ( $a$ geometric average in levels of the sectoral prices) of the sectoral deflators for simplicity even though in practice this equation must be regarded as only an approximation to the deflator series appearing in the national income accounts.

Real exchange rates: GDP deflators

The first series for the real exchange rate which are of interest are those based on the GDP deflator as a whole and the deflator for traded goods alone. 


$$
\begin{aligned}
R_{V} & =P_{V}^{*}+X-P_{V}, \\
R_{V T} & =P_{V T}^{*}+X-P_{V T} .
\end{aligned}
$$

We define these two series for the yen-dollar exchange rate, $X$, where the starred variables represent those of the United States and the unstarred variables those of Japan. (Japan thus is the "home country"). Equation (5) expresses the aggregate real exchange rate relative to the real exchange rate for traded goods as the difference of two relative prices: the relative price of nontraded to traded goods in the United States and the corresponding relative price in Japan.

$$
R_{V}-R_{V T}=g *\left(P_{V N}^{*}-P_{V T}^{*}\right)-g\left(P_{V N}-P_{V T}\right)
$$

The coefficients, $g$ and $g^{*}$, represent the share of nontraded goods in total value added. The equation shows that a rise in nontraded relative to traded prices in Japan leads to a real appreciation of the yen in terms of the GDP deflator as a whole relative to the traded goods deflator. Thus the yen has to appreciate in terms of the aggregate index in order for U.S. traded goods to remain competitive. We later provide estimates of how large that appreciation has to be.

The real exchange rate for traded goods alone can be expressed in terms of relative wages and relative productivity if we use equations $3 a$ and its counterpart for the foreign country (assuming as before that markups are constant):

$$
R_{V T}=R_{U L C T}=\left[\left(W_{T}^{*}+X-W_{T}\right)-\left(H_{T}^{*}-H_{T}\right)\right] .
$$

The expression in brackets on the right side of equation 6 represents relative unit labor costs (in this case, in the traded sector alone), RULCT. 
Substituting this expression into equation 5 along with the expressions for the sectoral prices $(3 a, 3 b)$, we obtain an equation for $R_{V}$ in terms of the production factors.

$$
R_{V}=R_{U L C T}+g^{*}\left[\left(W_{N}^{*}-W_{T}^{*}\right)-\left(H_{N}^{*}-H_{T}^{*}\right)\right]-g\left[\left(W_{N}-W_{T}\right)-\left(H_{N}-H_{T}\right)\right] .
$$

This equation states that the aggregate real exchange rate (that based on the GDP deflator) is influenced by two factors: relative unit labor costs in the traded sectors of the United States and Japan and unit labor costs in one sector of each national economy relative to the other sector. If unit labor costs in the traded and nontraded sectors of each country move together, then the real exchange rate will follow relative unit labor costs in the traded sectors of the two countries. But if, for example, there is a faster rate of growth of productivity in the traded sector of Japan, then the real exchange rate of the yen will have to appreciate relative to $R_{U L C T}$ in order to keep the traded sector of the United States competitive. The relatively greater productivity in the traded sector of Japan will induce higher wages in that sector, and in the nontraded sector as well unless the labor market is segmented. As a result, the relative price of nontraded goods will $r$ ise in Japan, thus pushing up the GDP deflator relative to traded prices or unit labor costs in the traded sector. If the yen depreciates in nominal terms enough to keep the real exchange rate based on the GDP deflator constant, Japanese traded goods will gain a price advantage. To keep U.S. traded goods competitive, therefore, the yen has to appreciate in real terms when measured relative to the GDP deflator (i.e., $R_{V}$ has to fall relative to $R_{U L C T}$ ). ${ }^{5}$

Real exchange rates: final goods prices

The real exchange rates that have received the most attention recently are not those based on GDP deflators, but on final goods prices. The two most 
frequently cited are the real exchange rates based on the consumer price index (CPI) and wholesale price index (WPI). In this section we develop expressions for two real exchange rates, one defined in terms of the final price of traded goods alone and another defined in terms of a general price index.

We begin by defining general price indexes for final goods, $P_{F}$ and $P_{F}^{*}$, consisting of domestic traded and nontraded goods, traded goods originating from the other country, and traded goods originating from third countries (with a dollar price of $\mathrm{P}_{W}^{*}$ ):

$$
\begin{gathered}
P_{F}=a_{1} P_{T}+a_{2} P_{N}+a_{3}\left(P_{T}^{*}+X\right)+a_{4}\left(P_{W}^{*}+X\right), \\
P_{F}^{*}=a_{1}^{*} P_{T}^{*}+a_{2}^{*} P_{N}^{*}+a_{3}^{*}\left(P_{T}-X\right)+a_{4}^{*} P_{W}^{*},
\end{gathered}
$$

where $a_{1}+a_{2}+a_{3}+a_{4}=1$ and similarly for the foreign country coefficients. $P_{F}$ and $P_{F}^{*}$ may be considered idealized forms of the consumer price index (with geometric weighting). The real exchange rate defined in terms of these general price indexes, $R_{F}=P_{F}^{*}+X-P_{F}$, can be expressed in terms of several relative prices as follows:

$$
\begin{gathered}
\mathrm{R}_{\mathrm{F}}=\left(1-\mathrm{a}_{3}^{*}-\mathrm{a}_{3}-\mathrm{a}_{4}\right)\left(\mathrm{P}_{\mathrm{T}}^{*}+\mathrm{X}-\mathrm{P}_{\mathrm{T}}\right)+\left(\mathrm{a}_{4}^{*}-\mathrm{a}_{4}\right)\left(\mathrm{P}_{\mathrm{W}}^{*}-\mathrm{P}_{\mathrm{T}}^{*}\right) \\
+\mathrm{a}_{2}^{*}\left(\mathrm{P}_{\mathrm{N}}^{*}-\mathrm{P}_{\mathrm{T}}^{*}\right)-\mathrm{a}_{2}\left(\mathrm{P}_{\mathrm{N}}-\mathrm{P}_{\mathrm{T}}\right) .
\end{gathered}
$$

According to this equation, $R_{F}$ is affected by the relative prices of traded goods originating from the United States and Japan, world prices relative to U.S. prices (although only to the extent that the coefficients of third country goods differ between the two countries), ${ }^{6}$ and by two terms representing sectoral relative prices in the two countries.

To see how $R_{F}$ varies relative to real exchange rates defined for traded goods alone, we first express $\mathrm{P}_{\mathrm{T}}$ and $\mathrm{P}_{\mathrm{N}}$ in terms of value added deflators and 
the prices of raw materials by solving equations (2a) and (2b):

$$
\begin{aligned}
& \mathrm{P}_{\mathrm{T}}=\mathrm{c}_{11} \mathrm{P}_{\mathrm{VT}}+\mathrm{c}_{12} \mathrm{P}_{\mathrm{VN}}+\mathrm{c}_{13} \mathrm{P}_{\mathrm{I}}, \\
& \mathrm{P}_{\mathrm{N}}=\mathrm{c}_{21} \mathrm{P}_{\mathrm{VT}}+\mathrm{c}_{22} \mathrm{P}_{\mathrm{VN}}+\mathrm{c}_{23} \mathrm{P}_{\mathrm{I}},
\end{aligned}
$$

where $c_{11}=c_{\mathrm{T} 1} / \mathrm{C}, c_{12}=\left(c_{\mathrm{T} 2} \mathrm{c}_{\mathrm{N} 1}\right) / \mathrm{C}, \mathrm{c}_{13}=\left(\mathrm{c}_{\mathrm{T} 3}+\mathrm{c}_{\mathrm{T} 2} \mathrm{c}_{\mathrm{N} 3}\right) / \mathrm{C}, \mathrm{C}=1-\mathrm{c}_{\mathrm{T} 2} \mathrm{c}_{\mathrm{N} 2}$ 0 , and $c_{11}+c_{12}+c_{13}=1$. The coefficients $c_{2 j}(j=1,2,3)$ are defined analogously. Using equation $10 \mathrm{a}$ and its counterpart for the foreign country, we obtain an expression explaining the movement of $R_{T}$ relative to $R_{V T}$, the real exchange rate based on gross output prices for traded goods $\left(\mathrm{P}_{\mathrm{T}}^{*}+\mathrm{X}-\mathrm{P}_{\mathrm{T}}\right)$ relative to that based on value added deflators for traded goods.

$$
\begin{aligned}
R_{T}- & R_{V T}=c_{12}^{*}\left(P_{V N}^{*}-P_{V T}^{*}\right)-c_{12}\left(P_{V N}-P_{V T}\right) \\
& +c_{13}^{*}\left(P_{I}^{*}-P_{V T}^{*}\right)-c_{13}\left(P_{I}-P_{V T}\right) .
\end{aligned}
$$

According to this equation, there are two sets of influences on $R_{T}-R_{V T}$ : the relative price of nontraded to traded goods in each country, reflecting primarily the bias in productivity growth between sectors, and the real price of raw materials (in terms of traded goods) in both countries.

We can now express the real exchange rate based on the general price index in terms of that based on the value added deflator for traded goods alone ${ }^{7}$

$$
\begin{aligned}
R_{F}-R_{V T} & =c_{1}\left(P_{V N}^{*}-P_{V T}^{*}\right)-c_{2}\left(P_{V N}-P_{V T}\right)+c_{3}\left(P_{I}^{*}-P_{V T}^{*}\right) \\
& -c_{4}\left(P_{I}-P_{V T}\right)-c_{5} R_{T}+c_{6}\left(P_{W}^{*}-P_{T}^{*}\right),
\end{aligned}
$$

where $c_{1}=\left(1-a_{2}^{*}\right) c_{12}^{*}+a_{2}^{*} c_{22}^{*}$,

$$
c_{2}=\left(1-a_{2}\right) c_{12}+a_{2} c_{22} \text {, }
$$




$$
\begin{aligned}
& c_{3}=\left(1-a_{2}^{*}\right) c_{13}^{*}+a_{2}^{*} c_{23}^{*}, \\
& c_{4}=\left(1-a_{2}\right) c_{13}+a_{2} c_{23}, \\
& c_{5}=\left(a_{3}^{*}+a_{3}+a_{4}\right), \\
& c_{6}=\left(a_{4}^{*}-a_{4}\right) .
\end{aligned}
$$

According to this equation, the gap between $R_{F}$ and $R_{V T}$ is influenced by changes in the relative prices of nontraded to traded goods or in the real prices of raw materials as well as by changes in the relative prices of traded goods. The yen appreciates more in terms of the broader index if there is a relatively greater $r$ ise in nontraded relative to traded prices in Japan. The reasoning is the same as in the comparison between the real exchange rate based on the GDP deflator and the narrower deflator for traded goods. In order to keep the United States competitive in its traded sector, the yen must have a real appreciation in terms of the broader general price index. A rise in the real price of raw materials in Japan (for a given real price of raw materials in the United States) also causes a greater appreciation in the broader index than in that based on traded goods alone. Finally, the gap between $R_{F}$ and $R_{V T}$ widens if there is an increase in the real exchange rate for traded goods, $\mathrm{R}_{\mathrm{T}}$. (The effects of a rise in third country prices are indeterminate).

In the next section, we will use these expressions for the various real exchange rates to interpret the movements of the yen relative to the dollar over the past twenty years. We begin by examining the GDP deflators derived from the national income accounts.

\section{REAL EXCHANGE RATES IN PRACTICE}

The OECD has published national accounts statistics defined on a consistent basis for the years 1964 to 1983. We have used the real and nominal GDP statistics disaggregated by type of activity to generate series 
for traded and nontraded goods. The corresponding employment figures disaggregated by type of activity start in 1970 , so the series we generate for productivity by sector only extend back to that year.

Finding operational counterparts to the traded and non-traded aggregates in equation (1) is not an easy task. The national accounts statistics of the OECD provides a breakdown of total value added into ten subsectors ranging from manufacturing to wholesale and retail trade. We have designated two subsectors as traded:

manufacturing, and agriculture, hunting, fishing, and forestry. A third subsector, mining and quarrying, undoubtedly has a large traded component, but this category includes energy products with prices very sensitive to OPEC price policy. Since we are interested in the relative impact of technological change on the traded and non-traded sectors, we chose to exclude any energy-intensive subsectors. The non-traded sector includes six of the remaining seven subsectors, but excludes one category, electricity, gas and water, because of its energy content. The non-traded subsectors are:

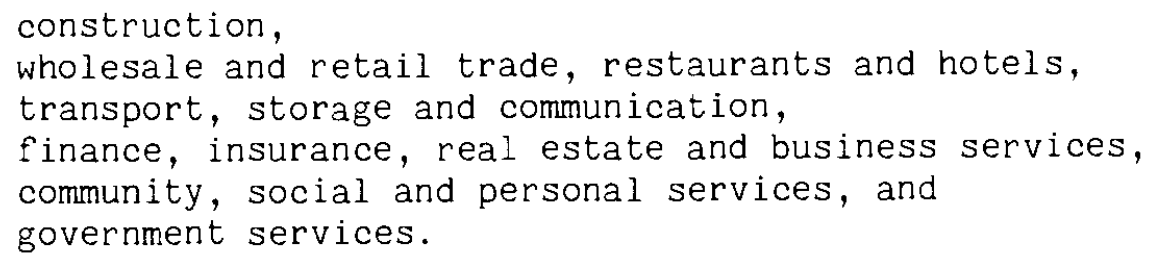

The division chosen is inevitably somewhat arbitrary. The manufacturing subsector, for example, includes goods which never enter into international trade. But this division is, in our judgement, the best available. The value added deflators for traded and non-traded goods are weighted averages of the subsector deflators, the weights being the relative size of value added in 1980. These same weights are used for all series subsequently defined for the traded and non-traded sectors. 
The real exchange rate based on the GDP deflator

The GDP deflator is a broad based price series reflecting price movements in both traded and nontraded sectors of an economy. Real exchange rates based on this series might be expected to provide a fairly reliable guide to the relative competitiveness of national economies. In comparisons between Japan and the United States, however, the GDP deflator offers a very distorted view of relative competitiveness because the traded and nontraded sectors follow quite divergent paths in one economy compared to the other. We begin by examining broad trends in real exchange rates as well as trends in productivity by sector. In Table 1 below, we report percentage changes in these series obtained by fitting each series to an exponential time trend over the 1973-83 period. The year 1973 is chosen as the starting point for the trend calculations because it is after the realignments associated with the Smithsonian Agreement on exchange rates and coincides with the advent of general floating in early $1973 .{ }^{8}$ The variables appearing in Table 1 are defined as follows:

$R_{V}$ : the real exchange rate based on the GDP deflator, $\mathrm{R}_{\mathrm{VT}}$ : the real exchange rate based on the traded goods portion of the GDP deflator,

$\mathrm{H}_{\mathrm{N}}^{*}-\mathrm{H}_{\mathrm{T}}^{*}$ : productivity in the nontraded sector relative to the traded sector in the United States,

$\mathrm{H}_{\mathrm{N}}-\mathrm{H}_{\mathrm{T}}$ : productivity in the nontraded sector relative to the traded sector of Japan. 


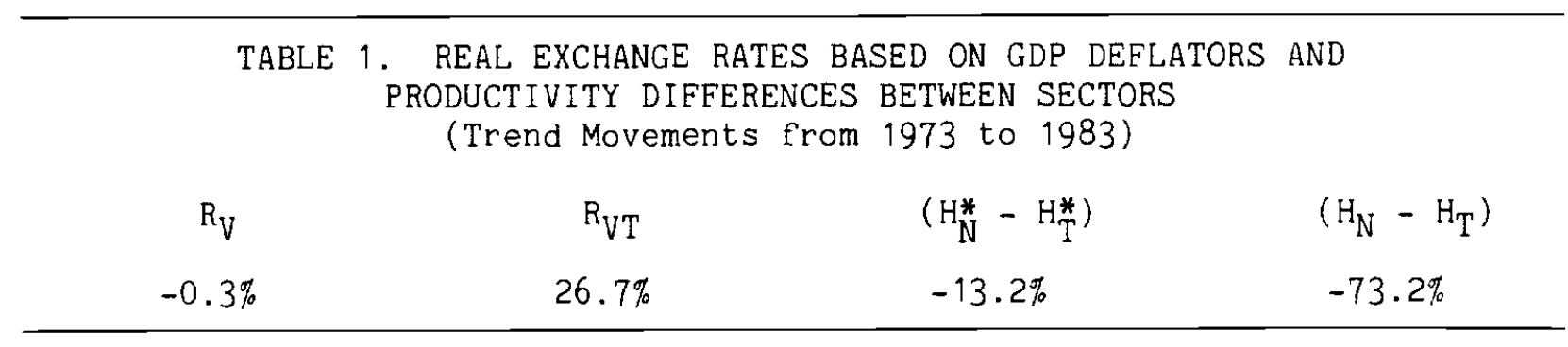

The percentage changes in these series are quite revealing.

(1) Over this period, the real exchange rate based on the GDP deflator followed a much different path than the real exchange rate based on the deflator for traded goods alone. From 1973 to 1983, the yen appreciated in terms of the GDP deflator by $0.3 \%$, while the real exchange rate defined in terms of the deflator for traded goods alone rose by $26.7 \%$, representing a sizable real depreciation of the yen or real appreciation of the dollar over the eleven year period. (This appreciation of the dollar is exceeded even further by the rise of $35.1 \%$ in the real exchange rate based on the deflator for manufacturing alone). If we were to focus exclusively on an aggregate index like the GDP deflator, we would conclude that the dollar had not appreciated much relative to the yen over the $1973-83$ period. ${ }^{9}$ Focusing on the traded sector, in contrast, leads to a very different conclusion. With a real appreciation of the dollar by $26.7 \%$ (or a real appreciation in manufacturing alone of $35.1 \%$ ), it is evident that the realignment following the Smithsonian Agreement has been undone by the strength of the dollar.

(2) What accounts for this divergence between the real exchange rates based on the GDP and traded goods deflators? The relatively small real depreciation in terms of the GDP deflator is explained by relative productivity movements in the traded and nontraded sectors of the United States and Japan. As equation (5) indicates, the difference between $R_{V}$ and $R_{V T}$ is a function of relative prices or, given similar sectoral wage trends, 
relative productivity movements in the traded and nontraded sectors of each country. ${ }^{10}$ Productivity in the U.S. traded sector grew by $13.2 \%$ faster than in the U.S. non-traded sector. But in Japan, productivity growth in the traded sector was $73.2 \%$ greater than in the non-traded sector. We can use equation (7) to calculate the trend differential between $R_{V}$ and relative unit labor costs in the traded sector, $R_{U L C T}$, based on these rates of productivity growth. The shares of nontraded goods in total GDP in the United States and Japan in 1980 were .733 and .657 , respectively, giving a differential between $\mathrm{R}_{\mathrm{V}}$ and $\mathrm{R}_{\mathrm{ULCT}}$ as follows: ${ }^{11}$

$$
\mathrm{R}_{\mathrm{V}}-\mathrm{R}_{\mathrm{ULCT}}=-.733\left[\mathrm{H}_{\mathrm{N}}^{*}-\mathrm{H}_{\mathrm{T}}^{*}\right]+.657\left[\mathrm{H}_{\mathrm{N}}-\mathrm{H}_{\mathrm{T}}\right]=-38.4 \%
$$

The markedly higher growth differential in Japan required a substantial real appreciation of the yen in terms of the GDP deflator, by $38.4 \%$ according to this calculation, to keep U.S. traded goods competitive. This relative appreciation, however, was accomplished not by $R_{V}$ falling, but by $R_{U L C T}$ rising. Because $R_{V}$ was nearly constant over the period, relative unit labor costs in the traded sector, and hence the relative prices of U.S. traded goods, rose significantly, by $38.1 \%$. This sharply reduced the relative competitiveness of U.S. exports.

Movements in real exchange rates over time are influenced by numerous short term demand factors in addition to the supply factors emphasized here. The difference between two real exchange rates, however, should be strongly influenced by supply factors. In the case of the value added deflators, these factors include the relative productivity movements in the nontraded and traded sectors of each economy. Below we report a regression for equation (5), relating the difference between $R_{V}$ and $R_{V T}$ to the price differential in the nontraded and traded sectors of each country. All variables are expressed 
as first differences in the logs, so they can be interpreted as percentage changes of the corresponding variables from one year to the next. The numbers in parentheses below the coefficients are t-statistics.

Sample Period 1971-83

$$
\begin{gathered}
\left(R_{V}-R_{V T}\right)=\underset{(3.72)}{.543}\left(P_{V N}^{*}-P_{V T}^{*}\right)-\underset{(-10.4)}{.679}\left(P_{V N}-P_{V T}\right), \\
\bar{R}^{2}=.708, \quad D W=1.97, \quad \text { S.E. }=.00891 .
\end{gathered}
$$

According to this equation, a $r$ ise in nontraded relative to traded prices in the United States leads to a $r$ ise in $R_{V}$ relative to $R_{V T}$, while a $r$ ise in nontraded relative to traded prices in Japan leads to a fall in $R_{V}$ relative to $\mathrm{R}_{\mathrm{VT}}$. Both coefficients are statistically significant at the $1 \%$ level, suggesting that annual movements in the real exchange rates relative to one another are strongly influenced by sectoral relative prices.

The annual movement of $R_{V}$ relative to $R_{U L C T}$ is also closely related to supply factors as suggested by equation (7). The second equation relates (the percentage change in) $R_{V}$ to (the percentage changes in) relative unit labor costs and sectoral productivity differentials in each country: ${ }^{12}$

Sample Period 1971-83

$$
\begin{gathered}
\mathrm{R}_{\mathrm{V}}=\underset{(7.40)}{.843} \mathrm{R}_{\text {ULCT }}-\underset{(-1.40)}{.943}\left(\mathrm{H}_{\mathrm{N}}^{*}-\mathrm{H}_{\mathrm{T}}^{*}\right)+\underset{(2.32)}{.692}\left(\mathrm{H}_{\mathrm{N}}-\mathrm{H}_{\mathrm{T}}\right) \\
\overline{\mathrm{R}}^{2}=.844, \quad \text { D.W. }=1.55, \quad \text { S.E. }=.044 .
\end{gathered}
$$

In this equation, (the percentage change in) $R_{U L C T}$ should enter with a positive coefficient close to one, depending on the markup of prices over marginal costs, while (the percentage changes in) $\mathrm{H}_{\mathrm{N}}^{*}-\mathrm{H}_{\mathrm{T}}^{*}$ and $\mathrm{H}_{\mathrm{N}}-\mathrm{H}_{\mathrm{T}}$ should have 
negative and positive coefficients, respectively. All of the coefficients, therefore, are of the correct sign, although the coefficient of $\left(\mathrm{H}_{\mathrm{N}}^{*}-\mathrm{H}_{\mathrm{T}}^{*}\right)$ is not statistically significant. Fitting this equation to the trend movements in the series reported in Table 1, we find that the gap between $R_{V}$ and $R_{U L C T}$ grows by $-44.3 \%$ over the $1973-83$ period, a little larger than in the calculation above based on sectoral shares. ${ }^{13}$ But the implications are similar: that the yen must appreciate significantly in real terms when measured against the GDP deflator as a whole if traded goods are to remain competitive.

Real exchange rates based on the prices of final goods

The prices of final goods follow patterns similar to those of GDP deflators, although in the case of the prices of final goods we have to take into account the influence of raw materials prices and the prices of final goods from third countries. We begin by examining trends in some of the key series over the post-Smithsonian period as reported in Table 2. The variables appearing in this table are defined as follows: 14

$\mathrm{R}_{\mathrm{C}}$ : real exchange rate based on the consumer price index,

$R_{\text {WPI }}$ : real exchange rate based on the wholesale price index,

$\mathrm{R}_{\mathrm{VT}}$ : real exchange rate based on the value added deflator for traded goods,

$\left(\mathrm{P}_{\mathrm{VN}}^{*}-\mathrm{P}_{\mathrm{VT}}^{*}\right),\left(\mathrm{P}_{\mathrm{VN}}-\mathrm{P}_{\mathrm{VT}}\right):$ relative GDP deflators for nontraded and traded goods in the United States and Japan,

$\left(P_{I}^{*}-P_{V T}^{*}\right),\left(P_{I}-P_{V T}\right):$ real price of raw materials in the United States and Japan (price of raw materials deflated by the value added deflator for traded goods). 
TABLE 2. REAL EXCHANGE RATES BASED ON THE WPI AND CPI INDEXES

AND RELATIVE PRICE CHANGES ACROSS SECTORS, U.S. AND JAPAN

(Trend Movements from 1973 to 1983)

$\begin{array}{ccc}R_{C} & R_{W P I} & R_{V T} \\ -9.0 \% & 4.4 \% & 26.7 \%\end{array}$
$\left(\mathrm{P}_{\mathrm{VN}}^{*}-\mathrm{P}_{\mathrm{VT}}^{*}\right)$
$\left(\mathrm{P}_{\mathrm{VN}}-\mathrm{P}_{\mathrm{VT}}\right)$
$\left(P_{1}^{*}-P_{V T}^{*}\right)$
$\left(\mathrm{P}_{\mathrm{I}}-\mathrm{P}_{\mathrm{VT}}\right)$

$12.3 \%$

$56.9 \%$

$8.0 \%$

$120.1 \%$

Over this eleven year period, the real exchange rate based on the CPI fell by 9\% (thus suggesting a real appreciation rather than depreciation of the yen), while all other real exchange rates rose. The real exchange rate based on the WPI rose only $4.4 \%$, however, a rate far below that based on the value added deflator for traded goods. This pattern of much greater real depreciations of the yen in the case of real exchange rates based on traded goods can be attributed to the sharp changes in relative prices evident in the second row of the table. The relative price of nontraded to traded goods rose much more in Japan than in the United States. When real exchange rates for final goods are being analyzed, the real prices of raw materials are also quite important. In Table 2, we report a much larger increase in the real price of raw materials in Japan than in the United States, the gap between the two countries being 112.1\%. This larger increase can be attributed to two factors: the greater increase in the local currency price of raw materials in Japan than in the United States (greater by $46.7 \%$ ), and relatively greater productivity in the traded sector of Japan which leads to a much smaller rise in the deflator for Japan, accounting for the rest of the differential in real terms. 15 Equation (12) summarizes the different influences on the real exchange rate based on a general price index such as the CPI. To illustrate the 
quantitative importance of these different influences, we assign values to the parameters appearing in equation (12), then calculate the trend change in $R_{F}-R_{V T}$ consistent with the trend changes in the independent variables appearing in Table 2. We have no estimates of $R_{T}$, the real exchange rate based on the traded prices of the United States and Japan. (Japan has an export price series for the 1973-83 period, but the United States only has series for individual commodities extending back that far). For this reason, the calculations below are based on the assumption that relative traded prices are constant. Thus in effect we are asking how much would $R_{F}$ have to vary relative to $R_{V T}$ in order for traded prices to be held constant over the 197383 period. 16

To simplify the analysis, we assume that the production and consumption parameters are identical for the United States and Japan. The values we assign to the parameters underlying those in (12) are as follows: ${ }^{17}$

$$
\begin{array}{llll}
\mathrm{a}_{2}=.6, & \mathrm{c}_{\mathrm{T} 1}=.65, & \mathrm{c}_{\mathrm{T} 2}=.2, & \mathrm{c}_{\mathrm{T} 3}=.15, \\
\mathrm{c}_{\mathrm{N} 1}=.8, & c_{\mathrm{N} 2}=.15, & c_{\mathrm{N} 3}=.05 .
\end{array}
$$

With these parameters and the actual trends in the relative prices appearing in equation (12), we find that $R_{F}-R_{V T}$ should have fallen by $37.4 \%$ over the 1973-83 period. This contrasts with an actual gap between the real exchange rate based on the CPI and that based on the value added deflator for traded goods of $35.7 \% .{ }^{18}$ The actual gap was achieved not by a fall in $R_{E}$, but primarily by a rise in $\mathrm{R}_{\mathrm{VT}}$.

We cannot estimate equation (12) as written since we have no series for $R_{T}$, the real exchange rate based on the final prices of traded goods. Instead, we estimate a modified version of (12) with $R_{T}$ omitted. ${ }^{19}$ All variables in the equation are expressed as first differences of the logs; the 
GDP data are available beginning in 1964, so the sample period spans nineteen years.

Sample Period 1965-83

$$
\begin{aligned}
& \left(R_{C}-R_{V T}\right)=\underset{(4.03)}{0.877}\left(P_{V N}^{*}-P_{V T}^{*}\right)-\underset{(-10.2)}{1.035}\left(P_{V N}-P_{V T}\right) \\
& +\underset{(1.78)}{0.082}\left(P_{I}^{*}-P_{V T}^{*}\right)+\underset{(0.52)}{0.015}\left(P_{I}-P_{V T}\right) \cdot \\
& \bar{R}^{2}=.753, \quad \text { D.W. }=1.97, \quad \text { S.E. }=.0146 .
\end{aligned}
$$

The coefficients of all variables with the exception of the last one have the correct sign, although neither of the coefficients for materials prices are statistically significant at the $5 \%$ level. The relative sectoral prices (the ratio of nontraded to traded prices) play a major role in this equation. The coefficients of these sectoral prices, in fact, may be larger than they should be given reasonable values of the underlying behavioral parameters. (Given the parameters assumed above, the first two coefficients in the regression should be about .6 in absolute value). The equation as a whole predicts a larger gap between $R_{C}$ and $R_{V T}$ than occurred over the 1973-83 period analyzed in Tables 1 and 2. Given the trends in relative prices for the independent variables in the estimated equation and the coefficients estimated above, there should have been a real appreciation of $R_{C}$ relative to $R_{V T}$ of $45.6 \%$, whereas in fact the relative appreciation was $35.7 \%$ (a sizable one, nonetheless). Despite the likely overestimation of the effects of Japanese sectoral prices, the equation reported explains a large proportion of the relative movement of the two real exchange rates, especially considering the fact that equation 12 on which this estimated equation is based abstracts from many short term influences on relative prices. 


\section{Implications for relative wage growth}

The tremendous growth in productivity in Japan, even if largely confined to the traded goods sector, has meant rising wages and standard of living in that country. In this section we use the model developed earlier to study the growth of wages in Japan relative to that in the United States implied by productivity growth and other factors affecting the relative competitiveness of traded goods in the two economies. We pose the following question: if during the 1973-83 period exchange rates had adjusted to keep traded goods competitive, what would have been the implications for relative wages in the two countries? The answer to this question differs considerably depending on whether we examine relative nominal wages or relative real wages.

We first determine the percentage change in relative nominal wages required to keep traded goods competitive. We substitute equations (6), (3a), and ( $3 b$ ) relating value added deflators to unit labor costs into equation (11) for $R_{T}$ to obtain:

$$
\begin{gathered}
\mathrm{R}_{\mathrm{T}}=\left(\mathrm{W}^{*}+\mathrm{X}-\mathrm{W}\right)-\left(\mathrm{H}_{\mathrm{T}}^{*}-\mathrm{H}_{\mathrm{T}}\right)-\mathrm{c}_{12}^{*}\left(\mathrm{H}_{\mathrm{N}}^{*}-\mathrm{H}_{\mathrm{T}}^{*}\right) \\
+\mathrm{c}_{12}\left(\mathrm{H}_{\mathrm{N}}-\mathrm{H}_{\mathrm{T}}\right)+\mathrm{c}_{13}^{*}\left(\mathrm{P}_{\mathrm{I}}^{*}-\mathrm{P}_{\mathrm{VT}}^{*}\right)-\mathrm{c}_{13}\left(\mathrm{P}_{\mathrm{I}}-\mathrm{P}_{\mathrm{VT}}\right) .
\end{gathered}
$$

If the real exchange rate for traded goods is held constant (for convenience we set its $\log , R_{T}$, equal to zero), we can express relative nominal wages as follows :

$$
\begin{gathered}
\left(W^{*}+X-W\right)=\left(H_{T}^{*}-H_{T}\right)+c_{12}^{*}\left(H_{N}^{*}-H_{T}^{*}\right) \\
-c_{12}\left(H_{N}-H_{T}\right)-c_{13}^{*}\left(P_{I}^{*}-P_{V T}^{*}\right)+c_{13}\left(P_{I}-P_{V T}\right) .
\end{gathered}
$$

Nominal wages in the United States relative to Japan (both expressed in dollars) are proportional to the following variables: 
$\mathrm{H}_{\mathrm{T}}^{*}-\mathrm{H}_{\mathrm{T}}$ : the gap between productivity in the traded sectors of the United States and Japan,

$\mathrm{H}_{\mathrm{N}}^{*}-\mathrm{H}_{\mathrm{T}}^{*}, \mathrm{H}_{\mathrm{N}}-\mathrm{H}_{\mathrm{T}}$ : the intersectoral productivity gap in each country,

$P_{I}^{*}-P_{V T}^{*}, P_{I}-P_{V T}$ : the real price of raw materials in each country. In Table 3, we 1 ist the trend changes in the five variables appearing in equation (13) over the 1973-83 period.

TABLE 3. TREND CHANGES IN PRODUCTIVITY AND RAW MATERIALS PRICES (Trend movements from 1973 to 1983)
$\mathrm{H}_{\mathrm{T}}^{*}-\mathrm{H}_{\mathrm{T}}$
$\mathrm{H}_{\mathrm{N}}^{*}-\mathrm{H}_{\mathrm{T}}^{*}$
$\mathrm{H}_{\mathrm{N}}-\mathrm{H}_{\mathrm{T}}$
$\mathrm{P}_{\mathrm{I}}^{*}-\stackrel{\mathrm{P}_{\mathrm{V}}^{*} \mathrm{~T}}{\mathrm{Q}}$
$\mathrm{P}_{\mathrm{I}}-\mathrm{P}_{\mathrm{VT}}$
$-83.4 \%$
$-13.2 \%$
$-73.2 \%$
$8.0 \%$
$120.1 \%$

The most interesting figure in this table is the huge gap of 83.4 percent between productivity growth in the traded sectors of the United States and Japan .

Using the figures for trend changes in Table 3 , we can calculate the change in relative nominal wages necessary to keep the relative prices of traded goods constant over the $1973-83$ period. With the same production coefficients assumed in Section II $b$, the trend change in $\left(W^{*}+X-W\right)$ is $-55.0 \%$ (expressed as a total percentage change over the $1973-83$ period). This relative wage change could occur through a greater $r$ ise in Japanese wages than U.S. wages when each is expressed in its own currency, or by a depreciation of the dollar. The actual trend change in relative wages was $-19.4 \%$, which suggests just how far U.S. wages must fall relative to Japanese wages, or more realistically, how much the yen must appreciate relative to the dollar, to keep the real exchange rate for traded goods constant over the 1973-83 period. The required growth of real wages is not as divergent as the growth of nominal wages because the growth of real wages in Japan is held down by the 
slow productivity growth in the nontraded sector. To calculate the growth of real wages in one country relative to the other, we must first obtain an estimate of the rate of change of the consumer price index consistent with the real exchange rate for traded goods remaining constant. We substitute into equation (9) expressions for the gross output prices of traded and nontraded goods (10a and 10b) and use equations (3a) and (3b) to express relative value added deflators in terms of productivity differentials. We then set the real exchange rate for traded goods equal to zero (as well as the relative price of third country goods) to obtain an expression for $R_{F}$ (or its empirical counterpart, $\left.R_{C}\right)$.

$$
\begin{aligned}
R_{E} & =R_{C}=-a_{2}^{*}\left(c_{22}^{*}-c_{12}^{*}\right)\left(H_{N}^{*}-H_{T}^{*}\right)+a_{2}\left(c_{22}-c_{12}\right)\left(H_{N}-H_{T}\right) \\
& +a_{2}^{*}\left(c_{23}^{*}-c_{13}^{*}\right)\left(P_{I}^{*}-P_{V T}^{*}\right)-a_{2}\left(c_{23}-c_{13}\right)\left(P_{I}-P_{V T}\right) .
\end{aligned}
$$

Using the coefficients assumed earlier, we find that in order for the real exchange rates for traded goods to remain constant, the real exchange rate for the CPI $\left(R_{C}\right)$ must fall by $17.7 \%$.

Real wages in the United States relative to that in Japan can be written as follows:

$$
\left(W^{*}-P_{C}^{*}\right)-\left(W-P_{C}\right)=\left(W^{*}+X-W\right)-R_{C}
$$

If $\mathrm{R}_{\mathrm{C}}$ falls by $17.7 \%$ over the $1973-83$ period, then real wage growth in Japan must exceed that of the United States by $37.3 \%$, a sizable amount but considerably smaller than the differential for nominal wages $(55.0 \%)$. In both countries, the slow rate of growth of productivity in the nontraded sector holds down the growth of real wages. But the imbalance between productivity growth in the two sectors of Japan is so great that the real exchange rate based on the CPI must fall significantly in order to keep traded goods 
competitive. This dampens the growth of real wages in Japan relative to the United States.

The manufacturing sector

Since such a large proportion of the traded sector consists of manufacturing goods, it is useful to examine manufacturing in more detail. There is considerable variation in productivity growth and competitiveness among the subsectors of manufacturing in the United States and Japan. This variation is superimposed on the trends within the manufacturing sector as a whole, so that some subsectors in the United States might fare well even in recent times when the dollar has been overvalued while other subsectors might suffer even during times of undervaluation.

The most extensive data providing a breakdown of manufacturing into subsectors are drawn from the GDP accounts of the United States and Japan. These data give a nine-sector breakdown for nominal and real GDP as well as employment, so we are able to construct real exchange rates based on value added deflators and productivity measures on a disaggregated basis. 20 The nine subsectors are listed in Table 4 together with the weights in the U.S. and Japanese GDP's. The third subsector, "Wood and wood products, including furniture", is of negligible importance for Japan, so we have omitted this subsector from our analysis. Subsector eight, "fabricated metal products, machinery and equipment," represents $44 \%$ of U.S. manufacturing and $50.3 \%$ of Japanese manufacturing, so the relative competitiveness of that subsector is of particular importance. 
TABLE 4. LIST OF SUBSECTORS EOR MANUFACTURING

1: Food, beverages and tobacco

2: Textile, wearing apparel and leather industries

3: Wood and wood products, including furniture

4: Paper and paper products, printing and publishing

5: Chemicals and chemical petroleum, coal, rubber and plastic products

6: Non-metallic mineral products except products of petroleum and coal

7: Basic metal industries

8: Eabricated metal products, machinery and equipment

9: Other manufacturing industries

M: Total for manufacturing

GDP weights for 1980:

$\begin{array}{lccccccccc}\text { Sector } & 1 & 2 & 3 & 4 & 5 & 6 & 7 & 8 & 9 \\ \text { U.S. } & .113 & .065 & .043 & .087 & .140 & .029 & .069 & .440 & .015 \\ \text { Japan } & .081 & .037 & .000 & .023 & .096 & .029 & .104 & .503 & .126\end{array}$

We begin by examining the real exchange rates or relative price for each subsector of manufacturing. These are illustrated in Figure 1 for eight subsectors as well as for manufacturing as a whole. In this figure, a rise in the real exchange rate or relative value added deflator for a given subsector represents a real depreciation of the yen or a gain in Japanese competitiveness in that subsector. In manufacturing as a whole, the real exchange rate based on the value added deflator rose by $35.1 \%$ (measured by fitting the real exchange rate series to a trend between 1973 and 1983). As Figure 1 illustrates, this trend for manufacturing masks a wide variation across subsectors. At one extreme, subsector one representing food saw a real appreciation of the yen by $30.8 \%$ over the 1973 to 1983 period. But at the other extreme, subsector eight registered a real depreciation of $67.5 \%$. This pattern across subsectors reflects shifts in comparative advantage as Japan increased its competitiveness in machinery and equipment, for example, at the expense of food, textiles, and other less technologically advanced products. 
These shifts in comparative advantage are most easily seen if we imagine that the real exchange rate for manufacturing as a whole had remained constant over the period; in that case, the real exchange rate for subsector 1 would have fallen by over sixty percent, while that for subsector five, representing chemicals and petroleum products, would have remained constant and that of subsector eight would have increased by about thirty-five per cent. In the United States, these shifts in comparative advantage would have implied shifts of employment within the manufacturing sector rather than necessitating net shifts out of manufacturing into the nontraded sector. These shifts within manufacturing would not necessarily have involved shifts in employment out of subsector eight, since relative prices are only one determinant of employment and since the United States could have maintained a price advantage relative to other competitors.

The pattern of real exchange rates across subsectors is closely related to relative productivity growth in the two countries. Figure 2 shows productivity growth in the United States and Japan measured as a trend over the 1973-83 period for the eight subsectors as well as manufacturing as a whole. In all but two subsectors, productivity growth in Japan exceeds that of the United States in the same subsector, in several cases by large percentages. But the magnitude of the gap varies widely. In subsector 9 , that gap is only $22 \%$ over the eleven year period, while in subsector 8 the gap is $155 \%$ (productivity growth being $178 \%$ in Japan and $23 \%$ in the United States). For manufacturing as a whole, the gap is $86 \%$.

The magnitude of the gap between productivity growth is important because it helps to determine how much relative unit labor costs vary between the two countries. The behavior of each sectoral real exchange rate, in turn, should be influenced very strongly by relative unit labor costs in that sector, and 
thus indirectly by relative productivity growth. This influence is confirmed by a comparison of the sectoral patterns in Figures 1 and 2 . The two subsectors where U.S. productivity growth exceeds that of Japan, food and nonmetallic mineral products (sectors 1 and 6 ), for example, are those where the relative price of U.S. goods has fallen over the same period. Similarly, the subsector where the gap between Japanese and U.S. productivity growth is greatest, subsector eight, is the one experiencing the greatest rise in U.S. prices relative to those of Japan.

Over the 1973-83 period, changes in real exchange rates reflected macroeconomic factors in addition to the structural influences emphasized in this paper. But the behavior of each sectoral real exchange rate relative to the real exchange rate for manufacturing as a whole should be primarily determined by differences in productivity growth. To examine this relationship, we modify equation ( $3 a$ ) so that it explains the value added deflator for manufacturing as a whole or, alternatively, each subsector of manufacturing. Define $R_{V M}, R_{V i}$ as the real exchange rates for manufacturing and for subsector $i$, respectively. Then the difference between these real exchange rates can be expressed as follows:

$$
R_{V i}-R_{V M}=\left[\left(W_{i}^{*}-W_{M}^{*}\right)-\left(W_{i}-W_{M}\right)\right]-\left[\left(H_{i}^{*}-H_{i}\right)-\left(H_{M}^{*}-H_{M}\right)\right] .
$$

Subsector $i$ will experience a greater $r$ ise in its real exchange rate to the extent the U.S. wages $r$ ise relatively faster in that subsector than in manufacturing as a whole (or Japanese wages rise more slowly). Similarly, the growth in $R_{V i}$ will exceed that of $R_{V M}$ to the extent that Japanese productivity growth in that subsector exceeds that for manufacturing as a whole (or U.S. productivity growth falls short in that subsector). 
We have no reliable data for wages by subsector. But we can compare productivity growth in subsector $i$ with that for manufacturing as a whole as well as the corresponding real exchange rates. Using the trend changes in these variables calculated previously (and reflected in Figures 1 and 2), we can determine the percentage changes in $\mathrm{R}_{V i}-\mathrm{R}_{V M}$ and $-\left[\left(\mathrm{H}_{i}^{*}-\mathrm{H}_{i}\right)-\right.$ $\left.\left(\mathrm{H}_{M}^{*}-\mathrm{H}_{M}\right)\right]$ over the 1973-83 period. The correlation between these two series over the eleven year period is .906 . This suggests that the pattern of changes in relative sectoral real exchange rates is strongly influenced by the pattern of productivity growth across sectors. The relative price changes that have occurred in the manufacturing sectors of these two countries, therefore, are longer term phenomena which will persist even if the current misalignment of the dollar is corrected.

CONCLUSION

This paper has provided estimates of the effects of relative productivity growth on real exchange rates and relative wage growth in the United States and Japan. With Japanese productivity growing $73.2 \%$ faster in its traded sector than in its nontraded sector over the $1973-83$ period, real exchange rates based on broad price indexes needed to adjust sharply to keep U.S. traded goods competitive. Since the adjustment of these real exchange rates has been minimal at best, U.S. traded goods have become much more expensive relative to Japanese goods. To maintain the competitiveness of the U.S. traded sector, the real exchange rate based on the GDP deflator would have had to fall by almost $40 \%$ relative to unit labor costs in the traded sector during the 1973-83 period. Similar adjustments would have had to occur in the real exchange rate based on the CPI and in relative nominal and real wages in the two countries. The recent misalignment of the dollar has prevented such adjustments. If U.S. traded goods are to regain their earlier competitiveness 
relative to Japanese traded goods, then the yen must appreciate considerably (relative to 1983 levels) when measured in terms of any broad-based price indexes.

Even if such a major adjustment in relative prices occurs, we will be left with equally large changes in competitiveness within the manufactured sector due to productivity differentials between subsectors of manufacturing. Japanese productivity growth in machinery production, for example, is nothing short of phenomenal (150\% above the United States over the 1973-83 period). These major shifts in relative prices taking place within the manufacturing sector compound an already serious problem of relative price adjustment. 


\section{EOOTNOTES}

*Prepared for the Conference on Real-Einancial Linkages in Open Economies, American Enterprise Institute, Washington D.C., January 30-31, 1986. I would like to thank the discussant of this paper, Rachel McCullough, as well as William Branson, Barry Eichengreen, Koichi Hamada, Paul Krugman, Robert Lipsey, and Charles Pigott for their helpful comments on an earlier draft. I would especially like to thank J. David Richardson for providing many useful suggestions concerning both content and presentation.

${ }^{1}$ Officer (1976b) provides a detailed description and critique of previous empirical studies. For more general studies of PPP, see the survey by Officer (1976a), Kravis et al. (1975), as well as the papers in the symposium on purchasing power parity in the May 1978 issue of the Journal of International Economics.

${ }^{2}$ Unlike Hsieh's study, most previous tests used cross-section data and focused as much on the level of the exchange rate as on its rate of depreciation.

3 In any case, with different cross-country relative price changes between sectors, PPP cannot hold for more than one type of price index.

${ }^{4}$ Marston and Turnovsky (1985) develop a two-level production function model in which value added has a Cobb-Douglas form and gross output a CES form (so that the elasticity of substitution between value added and raw materials can be below one). A linearization of the CES function results in an equation in the percentage changes of the variables very similar to those presented here.

${ }^{5}$ There is an interesting parallel between the traded-nontraded model and a model of three traded goods developed by W. Arthur Lewis (1978). The three traded goods in Lewis's model are primary commodities (produced by a 
developing country), manufactures (produced by a developed country), and an agricultural good such as wheat (common to both countries). In both models, productivity in producing the common good determines wages in the respective economies and, indirectly, prices for the other good. I am indebted to William Branson for pointing out this parallel.

${ }^{6}$ We might also have allowed for different price indexes for world goods imported into Japan and the United States, respectively.

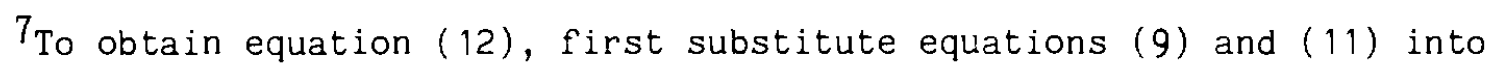
the expression $R_{F}-R_{V T}=\left(R_{F}-R_{T}\right)+\left(R_{T}-R_{V T}\right)$. In the resulting equation, replace $\mathrm{P}_{N}-\mathrm{P}_{\mathrm{T}}$ and $\mathrm{P}_{\mathrm{N}}^{*}-\mathrm{P}_{\mathrm{T}}^{*}$ by their value added counterparts using equations (10a) and (10b) (and the corresponding equations for the foreign country): $\mathrm{P}_{\mathrm{N}}-\mathrm{P}_{\mathrm{T}}=\left(\mathrm{c}_{22}-\mathrm{c}_{12}\right)\left(\mathrm{P}_{\mathrm{VN}}-\mathrm{P}_{\mathrm{VT}}\right)+\left(\mathrm{c}_{23}-\mathrm{c}_{13}\right)\left(\mathrm{P}_{\mathrm{I}}-\mathrm{P}_{\mathrm{VT}}\right)$.

8 We do not attempt to assess whether the yen and dollar were in equilibrium in 1973, nor to measure the current equilibrium value of the yendollar exchange rate. Artus and Knight (1984) and Williamson (1985) discuss some of the conceptual problems involved in determining the equilibrium value of an exchange rate. In measuring trend changes in real exchange rates over the 1973-83 period, we are instead trying to assess the impact of differential productivity trends on movements in real exchange rates relative to one another.

${ }^{9}$ The corresponding figure of $49.3 \%$ over the shorter period from 1978 to 1983 is more alarming, but that is measuring the appreciation of the dollar from a period of unusual weakness.

${ }^{10}$ There are no reliable data on wages in the nontraded sector of the economy, so the growth in the wage differential between sectors is omitted from the equations described below. If labor is mobile between sectors, or if bargaining over wages is strongly influenced by wages in the other sector, any 
growth in intersectoral wage differentials should be small compared with the gap in productivity growth rates between sectors.

${ }^{11}$ The share of nontraded goods in total GDP, represented by the coefficients $g^{*}$ and $g$ in equations (5) and (7), is likely to change through time as relative productivity differentials reduce traded prices relative to nontraded prices. Equation (7), therefore, will hold only as an approximation even if the markup of prices over unit labor costs is constant over time.

${ }^{12}$ In the measurement of relative unit labor costs, we employ U.S. Bureau of Labor Statistics (BLS) data on hourly compensation in manufacturing which are among the most reliable data available.

13 The coefficient of $R_{\text {ULCT }}$ is not significantly different from one at the $5 \%$ level. If we set this coefficient equal to one, the implied change in $R_{V}$ relative to $R_{U L C T}$ is $-38.3 \%$, almost identical to the figures based on sectoral shares.

${ }^{14}$ The CPI and WPI indexes as well as the spot exchange rate (period average) are taken from the $\mathrm{IMF}^{\prime} \mathrm{S}$ International Financial Statistics. The prices of raw materials, which include fuel as well as other materials for processing, are taken from the disaggregated wholesale price statistics of each country.

${ }^{15}$ The smaller increase in raw materials prices in the United States can be attributed in part to the price controls on petroleum products which were maintained through much of the period, although it is doubtful that this factor alone could account for such a large differential between the United States and Japan.

16 The relative prices of traded goods between third countries and the United States are also assumed constant. 


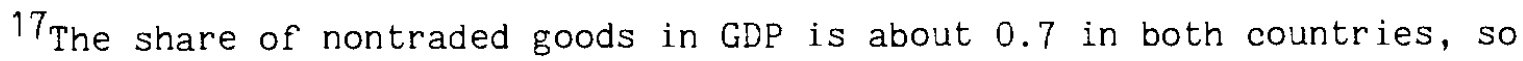
we assign a value of 0.6 to its share in gross output. We allow nontraded goods to play a somewhat larger role in traded goods production than vice versa to reflect the relatively larger service component of traded goods. Notice also that the share of raw materials in gross output is larger in the traded than in the nontraded sector.

18 The gap between the real exchange rate based on the wholesale price index and that based on the value added deflator for traded goods is only $22.3 \%$, but the WPI is heavily weighted toward manufacturing goods.

${ }^{19} \mathrm{R}_{\mathrm{T}}$ should have a relatively small effect on the differential, $R_{C}-R_{V T}$, since the coefficient $c_{5}$ should be small. Its omission from the equation, therefore, should not make much difference. The third country price variable is even less likely to be important in an equation explaining bilateral exchange rates. (See the coefficient $c_{6}$ which is equal to the difference between the country coefficients). When we proxied $R_{T}$ with $R_{V T}$, the real exchange rate based on the value added deflator for traded goods, the coefficient of $R_{V T}(.022)$ was statistically insignificant (with a t-statistic of .341) and the remainder of the equation remained almost unchanged. The adjusted R-squared fell from .753 to .737 .

${ }^{20}$ The disaggregated GDP data are undoubtedly of less uniform quality than the aggregate GDP data, but the broad trends in these data should be instructive, nonetheless. 


\section{REFERENCES}

Artus, Jacques R. and Malcolm D. Knight, 1984. Issues in the Assessment of the Exchange Rates of Industrial Countries, Occasional Paper No. 29. Washington: International Monetary Fund.

Balassa, Bela, 1964. The Purchasing Power Parity Doctrine: A Reappraisal. Journal of Political Economy. 72: 584-96.

Balassa, Bela, 1973. Just How Misleading Are Official Exchange Rate Conversions: A Comment. Economic Journal. 83: 1258-67.

De Vries, Margaret G., 1968. Exchange Rate Depreciation in Developing Countries. International Monetary Fund Staff Papers. 15: 560-78.

Clague, Christopher, and Vito Tanzi, 1972. Human Capital, Natural Resources, and the Purchasing Power Parity Doctrine: Some Empirical Results. Economia Internazionale. 25: 3-18.

Hsieh, David A., 1982. The Determination of the Real Exchange Rate: The Productivity Approach. Journal of International Economics. 12: 355-62.

Kravis, Irving, Zoltan Kenessey, Alan W. Heston, and Robert Summers. A System of International Comparisons of Gross Product and Purchasing Power. Baltimore: Johns Hopkins Press.

Lewis, W. Arthur, 1978. The Evolution of the International Economic Order (Eliot Janeway Lecture, 1977). Princeton: Princeton University Press.

Marston, Richard C., and Stephen J. Turnovsky, 1985. Imported Materials Prices, Wage Policy, and Macroeconomic Stabilization. Canadian Journal of Economics. 18: 273-84.

Officer, Lawrence, 1976a. The Purchasing Power Parity Theory of Exchange Rates: A Review Article. International Monetary Fund Staff Papers. 23: $1-60$.

Officer, Lawrence, 1976b. Productivity Bias and Purchasing Power Parity: An Econometric Investigation. International Monetary Fund Staff Papers. 23: $545-79$.

Williamson, John, 1985. The Exchange Rate System, Policy Analyses in International Economics 5, 2nd Edition. Washington: Institute for International Economics. 
\% CHANGE 1973 TO 1983

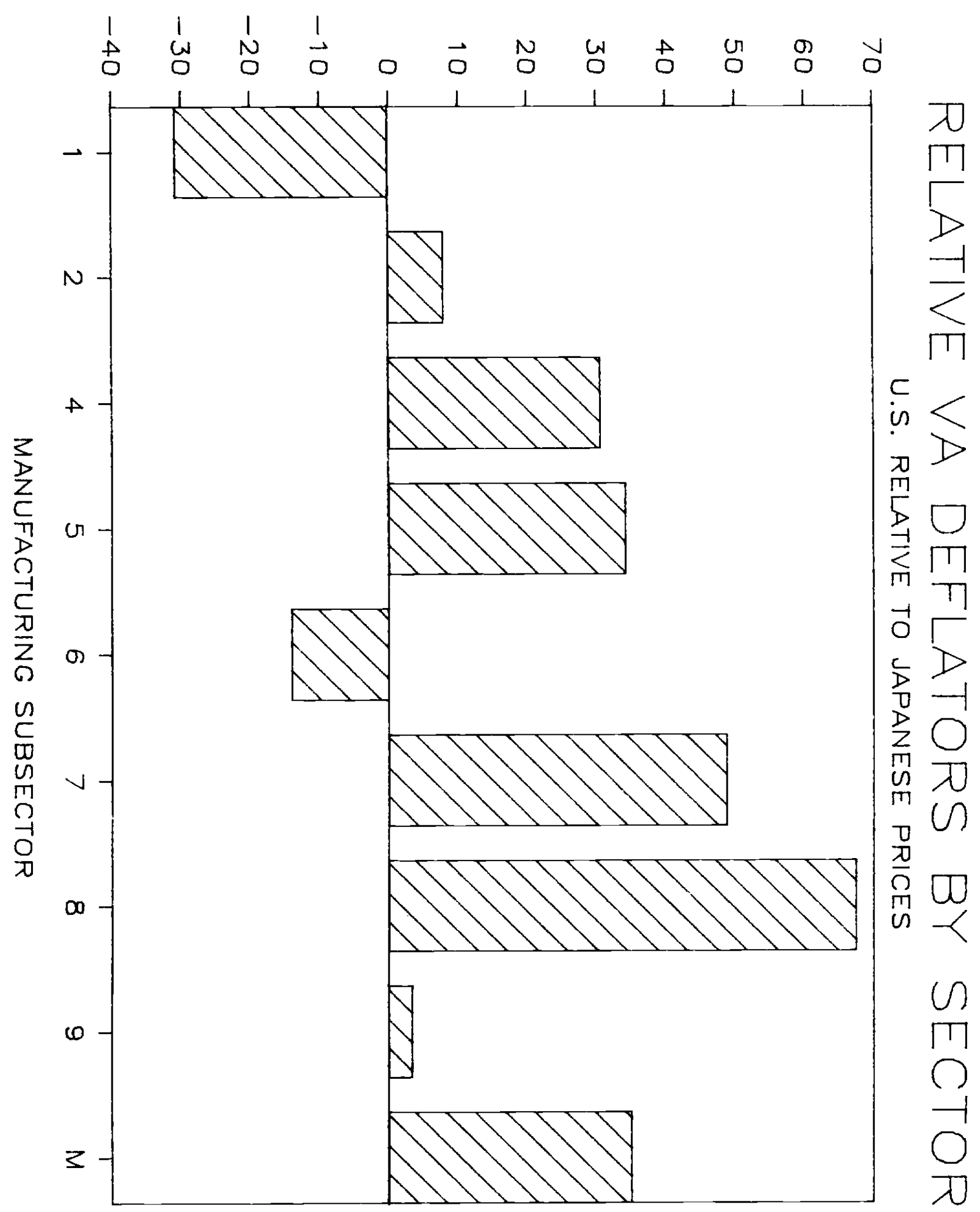


\% CHANGE 1973 TO 1983

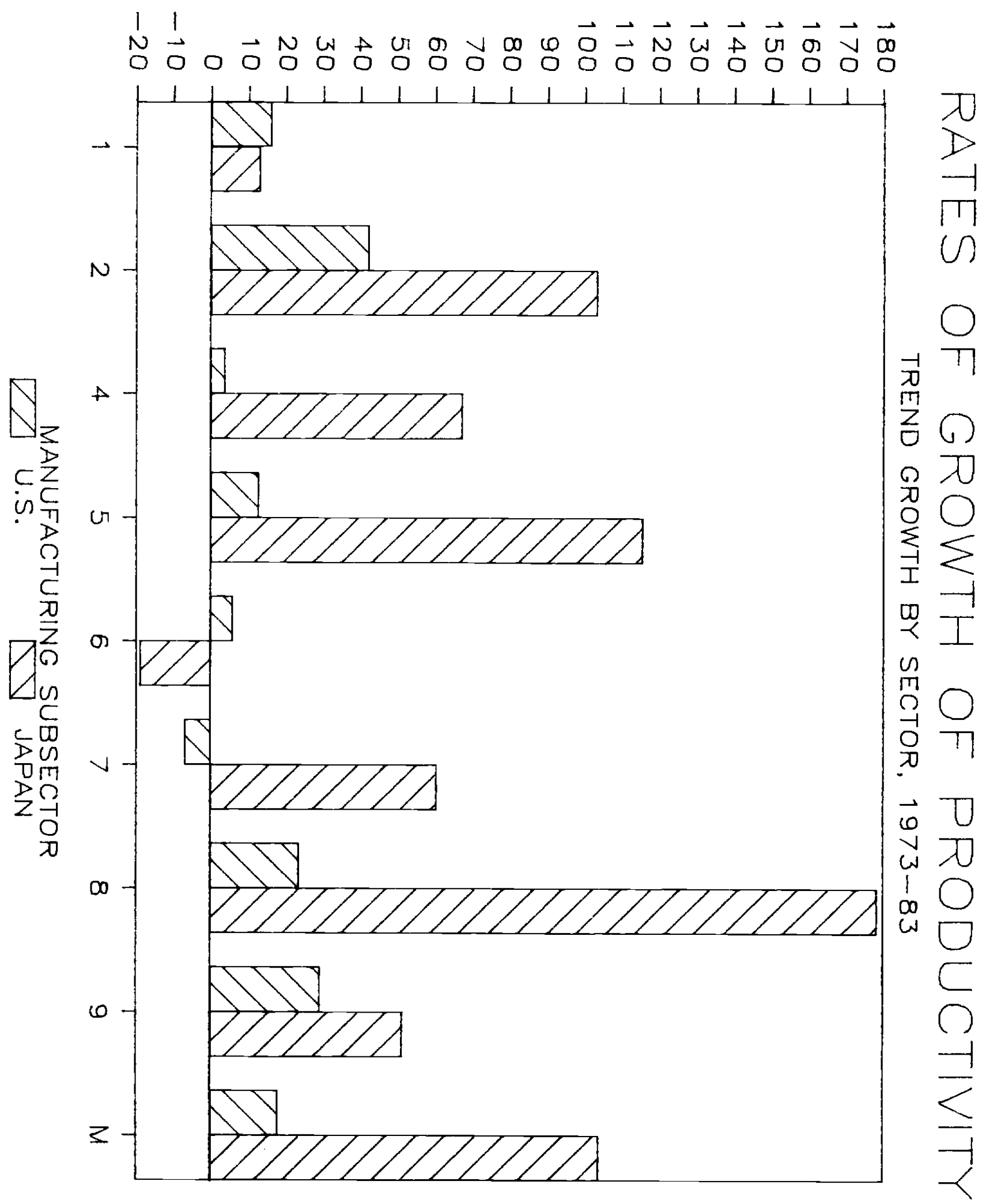

